\title{
Ebelik Uygulamalarında Mahremiyetin Önemi
}

\author{
The Importance of Privacy in Midwifery Practices
}

\author{
Hediye BEKMEZCí丶 Hava ÖZKAN ${ }^{\mathrm{b}}$
}

\begin{abstract}
Özet
Mahremiyet, başkaları tarafından kişinin beden, his, düşünce ya da kendisi veya ilişkilerine ait bilgilerine erişmenin sınırlanması anlamına gelmektedir. Gizlilik, gizli olma durumu, mahremiyet olarak tanımlamaktadır. Gizlilik de hasta mahremiyetine saygı göstermenin bir yoludur. Uluslararası Aile Planlaması Federasyonu'nun tüm bireylerin, kişisel, ev, aile ve haberleşme mahremiyetlerinin ihlal edilmemesi hakkına sahip olduklarını ve bilgilendirme ve danışmanlığın da içinde yer aldığı tüm cinsel sağlık ve üreme sağlığı hizmetlerinde mahremiyet ve kişisel bilgilerin gizli kalması sağlanması bu bildirgenin mahremiyet hakkı maddesinde vurgulanmıştır. Mahremiyet kavramı insanların bulunduğu her ortamda, insana ait her alanda kullanılmaktadır. Tıp alanındaki uygulamalarda ise hastanın mahremiyeti çok önemlidir. Obstetrik-jinekolojik değerlendirme ve muayene esnasında kadının mahremiyetinin ihlal edilmesi kadınlarda utanma duygusu ve korkunun yoğun yaşanmasına neden olmaktadır. Mahremiyet, sağlık bakımı alanların psikolojik fonksiyonlarını desteklediğinden dolayı önemlidir. Kaliteli hizmeti hedefleyen sağlık kurumları için, genel olarak hasta haklarının, özellikle mahremiyetin ve bilgilerin gizliliğinin korunmasına yönelik yasal ve kurumsal düzenlemelerin oluşturulması ve işlerliğinin sağlanması vazgeçilmez öğelerdir. Bu amaçla sağlık çalışanları ve özellikle de ebeler muayene, tedavi ve tanısal işlemlerde hastanın bedenini ve özel hayatını açmasını, sırlarını açıklamasını gerektiren işlemleri mahremiyet ortamında gerçekleştirmelidir.
\end{abstract}

Anahtar sözcükler: Mahremiyet, ebe, uygulama, jinekolojik muayene, doğum

\begin{abstract}
Privacy means the restriction for a person to access to information regarding her/his body, feelings, thoughts or information regarding her/himself or her/his relationships by other people. Confidentiality is defined as the state of being private and the privacy. Confidentiality is also a way of respecting the patient privacy. The item of the International Planned Parenthood Foundation regarding the right of privacy emphasizes that all individuals have the right to have their personal, home, family and communication privacy inviolated and keep their privacy and personal information confidential in all sexual health and reproductive health services including the information and counseling. The concept of privacy is used in every environment where human being exist, as well as every area that belongs to human beings. On the other hand, the patient privacy is very important in medical practices. Violating the privacy of women during the obstetrical-gynecological evaluation and examination causes an intense sense of shame and fear in women. Privacy is important since it supports the psychological functions of healthcare areas. The formation and operability of legal and institutional regulations aimed at the protection of generally patient rights, and especially the privacy and the confidentiality of information are indispensable elements for medical institutions targeting a quality service. For this purpose, healthcare professionals and especially the midwives should realize the procedures requiring the reveal and explanation of patient's body, private life and secrets in a private environment during the examination, treatment, and diagnostic procedures.
\end{abstract}

Key words: Privacy, midwives, practice, gynecological examination, birth

\footnotetext{
${ }^{a}$ Arş. Gör, Atatürk Üniversitesi Sağlık Bilimleri Fakültesi, Erzurum hediye.bekmezci@hotmail.com

${ }^{\text {b }}$ Yazışma Adresi: Yrd. Doç. Dr. Atatürk Üniversitesi Sağlık Bilimleri Fakültesi, Erzurum,

e-mail:havaorhan67@hotmail.com

Geliş Tarihi:07.11.2014/Kabul Tarihi:05.01.2015

*Çalışma I. Uluslararası 5. Ulusal Ebelik Öğrenci Kongresi'nde poster bildiri olarak sunulmuştur.
} 


\section{Giriş}

Dünya Sağlık Örgütü sağlığı "Yalnızca hastalık ve sakatlığın olmayışı değil, fiziksel, sosyal ve ruhsal yönden tam bir iyilik halidir" şeklinde tanımlamıştır. ${ }^{1}$ İnsan, fiziksel, sosyal, duygusal ve entelektüel gereksinimleri olan bir bütündür. Abraham Maslow, insanın temel gereksinimlerini temelden yukarı doğru hiyerarşik bir düzende sıralamıştır. ${ }^{2}$ Maslow, 1960'lı y1llarda gereksinimler hiyerarşisinde, maneviyat ve moral değerlere en üst basamakta yer vermiştir. Virginia Henderson'da bakım mesleklerinin amacının; bireyin temel gereksinimlerini karşılamada bağımsız hale getirmek olduğunu belirtmiş; bu temel gereksinimlerin, fizyolojik, psikolojik, sosyolojik, spiritüel ve entelektüel alanlardan oluştuğunu ileri sürerek 14 temel gereksinimi tanımlamıştır. İnsanın bütünlüğü düşünüldüğünde tüm boyutlarının dengeli olması durumunda sağlıklı olmasından söz edilebilir. ${ }^{1}$ Sağlık alanındaki uzmanların mahremiyetin önemini vurgulama çabalarına rağmen bu konuda özellikle ebelik/hemşirelik alanında yetersiz sayıda çalışma vardır. Hasta haklarına ilişkin yapılan düzenlemeler ve yenilikler Türk sağlık sisteminde, mahremiyet kavramı son 10-15 yıldır konuşulmaktadır; fakat hasta mahremiyeti üzerinde özel araştırmalar yapılmamıștır. ${ }^{3}$ Sağlık bakımının sunumunda temel bir değer olan mahremiyete saygı gösterilmesi insan ve üreme haklarındandır.

Bireyin mahremiyet hakkının
tanınması ve özellikle ebelik
uygulamalarında bu hakka dikkat çekmek
amacıyla bu derleme yazılmıştır.

\section{Mahremiyetin Tanımı}

Mahremiyet hakkı ilk olarak, 1890 yılında Warren ve Brandie tarafindan ele alınmıştır. Warren ve Brandie, toplumda bireylerin yasal güvenliğini sağlarken, düşünceleri ve duygularının başkaları ile paylaşılacak bölümü ile ilgili her bireyin karar verme hakkının olması gerektiğine değinmişlerdir. ${ }^{4}$

Mahremiyet kavramını ilk kez ele alan Altman'a ${ }^{5}$ göre mahremiyet insanın temel gereksinimlerinden biridir ve mahremiyette bireyin kişisel kontrolü önemlidir. ${ }^{6}$ Türk Dil Kurumu (TDK) mahremiyeti, gizlilik olarak tanımlamaktadır. ${ }^{7}$ Mahremiyet kavramı felsefi anlamını bireyin bağımsız, tikel bir varoluşa sahip olduğu anlayışında bulur. Onun kendi benliğinin bilincine sahip olarak kendi kararlarını verebilme özelliği, tüm diğer bireyler karşısında sahip olunan dokunulamaz ve bağımsız varlık alanınıntikel varoluşa sahip olmasınıntemellendirilmesini sağlar. $\mathrm{Bu}$ nedenle benliğin bilincine sahip olma, tikel varoluşun onaylanması anlamında mahremiyet kavramının dayanağını oluşturur. ${ }^{8}$ Mahremiyet kavramının evrensel bir tanımı yoktur. Ancak, mahremiyetin genel olarak kabul edilen yönü temel insan gereksinimi ve hakk1 olmasıdır. $^{3}$ Mahremiyet, başkaları tarafından kişinin beden, his, düşünce ya da kendisi veya ilişkilerine ait bilgilerine erişmenin sınırlanması anlamına gelmektedir. Mahremiyet bir "varlık", bir "insan olma" durumudur. Başkaları tarafindan yapılacak fiziki ya da düşünsel müdahaleleri kontrol etme hakkı insana sayg1 ilkesinden temel alır. Bunun anlamı özerkliğe saygıdır ve onların yararı için davranmaktır. Gerçek anlamda özerk olmak, bireyin diş etkilerden uzak olmasidır. ${ }^{9} \quad$ Bununla birlikte, insanın günlük yaşantısının çok önemli bir parçasını oluşturan mahremiyet hakk1, başkalarından tamamen soyutlanmak veya tümüyle ilişkisini kesmek anlamına gelmez. Sadece kişinin, hayatını başkalarıyla ne ölçüde paylaşacağını belirleme hakkına sahip olduğunu ifade eder. ${ }^{10}$ Genel olarak mahremiyetin, bir insanın mahrem yerlerine bakılmasının, dokunulmasının ve hakkında konuşulmasının/ dinlenilmesinin yasaklanması şeklinde tanımlanabilir. ${ }^{11}$ 
Kültürden kültüre ve aynı toplum içerisinde zamandan zamana farklılık gösteren mahremiyet, birçok insan için aynı anlama gelmemesi ve belli bir sınırının olmaması nedeniyle önemli bir kavramdır. Mahremiyet konusunun sadece belli bir bilim alanın değil, insanın olduğu tüm alanlarda önemli olduğu unutulmamalıdır. ${ }^{12}$

\section{Sağlık Uygulamalarında Mahremiyet}

Mahremiyet kişisel bütünlükle ilgilidir. Temel bir insan hakkıdır ve hem pozitif hem de negatif haklarda yer bulmaktadır. Pozitif hak olarak mahremiyet kişinin kişisel bilgiyi, mülkünü ya da eylemlerini kontrol etme, paylaşma hakkına sahip olduğu anlamındadır. $\mathrm{Bu}$ mahremiyetin sadece o kişinin izniyle ihlal edilebileceği anlamina gelmektedir. Klinikte, mahremiyet hakkı gibi pozitif hakların korunması konusunda kuşku verici örnekler bulunmakla birlikte, olağan koşullarda bireyin tıbbi kayıtlarının paylaşımı bu hakkın kapsamı dâhilindedir ve "izne" tabidir. Bireyin mahremiyetine müdahaleyi engelleyen negatif haklar ise, klinikte hastanın bilgilerinin sadece tıbbi kararın tarafi olan diğer hekim, ebe/hemşire ya da hastanın onayladığı aile üyeleriyle paylaşılmayı gerektirmektedir.

$\begin{array}{ccc}\text { Manevi gereksinimler ve psiko- } & \text { geriksel } \\ \text { sosyal } & \text { gereksinimler, } & \text { fizikse }\end{array}$ gereksinimlere göre daha soyut ve karmaşık olup aynı zamanda ölçümü güçtür. $\mathrm{Bu}$ nedenle bireyin sağlik bakımında daha net ve kolaylikla ölçülebilen fiziksel gereksinimler öncelikle ele alınmakta, buna karşılık manevi gereksinimler ihmal edilebilmektedir. Ancak bireylerin manevi gereksinimlerinin de tanımlanması ve gerekli bakımın sağlanması önemlidir. ${ }^{14-17}$ Sağlık alanında mahremiyet; fiziksel, sosyal, psikolojik ve bilgi yönleriyle düşünülebilir.

$$
\text { Sağllk alanında fiziksel }
$$
mahremiyet; Hastanede, hasta odalar1; kişilerin düzen, 1şıklandırma, renk, sıcaklık bakımından evlerinden farklı olup, hastalar kendi istek ve kontrollerine göre bir çevre ayarlayamazlar. Hastaların kişisel alanlarının sinırlandirılması ve bu alanlara (odalarına veya vücutlarına) müdahale doğrudan mahremiyetlerine müdahale edilmesi anlamına gelir. ${ }^{3}$ Bireyin onamı olmadan tıbbi işlemlere tabi tutulmaması ve bilgilendirildikten sonra izin verdiği ve talep ettiği işlemlere (tıbbi sakınca olmadıkça) tabi tutulması, bireyin beden mahremiyeti hakkının sonucudur. $\mathrm{Bu}$ anlamda zorla yapılan kısırlaştırma, gebeliği sonlandırma, doğurganlığı önleme gibi faaliyetler mahremiyet hakkına müdahale olarak kabul edilir. Aynı şekilde -tıbbi açıdan bir sakınca olmadıkça- talep edilen müdahalenin gerçekleştirilmemesi de bireyin bedeni üzerindeki haklarına müdahale olarak kabul görmektedir. Kadınların, sterilizasyon, RİA uygulaması, istemli düşük taleplerinin kabul edilmemesi beden mahremiyeti haklarının ihlali anlamina gelecektir. $\mathrm{Bu}$ gibi konularda bireyler, kendi beden bütünlüklerine müdahale konusunda tek başlarına karar verici olmalı, bir başkasının onayına bağlı kalmamalıdır. Ancak zihinsel yetersizliği olan, yasal açıdan tek başına karar veremeyecek olan (18 yaşını doldurmamış) kadınlar açısından, evli olmaları ya da evli olmamaları halinde, hak ihlali oluşturabilecek düzenlemelerin bulunduğu da bilinmektedir. Beden üzerinde gerçekleştirilecek işlemler konusunda bir başka bireyin karar verme sürecine dahil edilmesinin özen isteyen bir uygulama olduğu unutulmamalıdır. ${ }^{18}$

Sağlık alanında sosyal mahremiyet; Bir etkileşimde bireyin kontrolünü ifade eder ve sağlık bakımında bu kontrol genellikle sağlık çalışanına geçmektedir. Profesyonel ilişkilerde mahremiyetin sağlanması ve sürdürülmesi bir haktır ve her hak karşıdakine (çalışanlara) bir şey yapma yükümlülügü (pozitif hak) ya da yapmama yükümlülüğü (negatif hak) getirmektedir. $^{3}$

Sağlık uygulamalarında psikolojik mahremiyet; Bireyin mahremiyet hakkının ihlali dışardan fark edilmese de derin izler 
bırakabilecek sorunlar oluşturmaktadır. Sağlık çalışanlarının rutine dayanan işleri yaparken bireyin mahremiyet hakkını düşünmemesi veya ihlali, kişinin kendisini değersiz hissetmesine, toplumsal alanlardan geri çekilmesine, kendine olan güvenini yitirmesine neden olabilmekte ve hastanede yattığ 1 süre içerisinde her an rahatsiz ve huzursuz hissetmesine yol açabilmektedir. Bu durum, bireyden bireye fark etmekle beraber kalıcı sorunlara da neden olabilmektedir. ${ }^{3}$

Sağllk uygulamalarında bilgi mahremiyeti; Türk Dil Kurumu gizliliği; gizli olma durumu, mahremiyet olarak tanımlamaktadır. ${ }^{7}$ Hekimin hastasına bir çeşit söz vermesi sayılan tıbbi gizlilik; her türlü bilgiyi içeren tıbbi kayıtların hastaya ait olduğu ve onun mülkiyet haklarıyla güvence altına alındığını varsayar. $\mathrm{Bu}$ nedenle hastane hastalara ait tıbbi bilgileri hastalarının gelecekteki tıbbi yararı adına emanet altına alır. Fakat pozitif hakkın gereği olarak hastanenin bu muhafaza görevi, hastaneyi tıbbi kayıtların sahibi durumuna getirmez. Tibbi kayıtlar her şekilde hastanın mülküdür. Gizlilik de hasta mahremiyetine saygı göstermenin bir yoludur. Çünkü Hipokrat döneminden beri mahremiyete sayg1, bireyin onurunu ve özerkliğini korumanın esasıdır. ${ }^{13}$ Bireylerin üreme ve cinsel yaşamları ile ilgili bilgiler yaşamlarının en mahrem alanları ile ilgilidir. Bireylerin cinsel sağlık ve üreme sağlığı ile ilgili hizmet alması sürecinde öğrenilen ve edinilen tüm bilgi ve belgelerin gizliliği sağlanmalıdır. Buradaki asıl amaç bireyin özel yaşamının korunması olsa da bu konudaki güvenceler, bireylerin bu hizmetlere ulaşmasında ve hizmetlerden yararlanmasinda da güvenini sağlayacaktır. Üreme sağlı̆̆ ve cinsel sağlı ile ilgili hizmet ve bilgilendirmelerde özel yaşama saygı ve bilgilerin gizliliğini korumak, çoğu zaman hizmete gereksinimi olanlar açısından hayati önem taşımaktadır. ${ }^{18}$

Sağlı uygulamaları bilgi üzerine temel oluşturur. Bilginin dağıtım ve toplama yönetimi, bilgi teknolojisindeki hızlı gelişmelerle ve elektronik kayıtlar ile güvenilmez olabilmektedir. Bilgi mahremiyetinin diğer yönü hastanın bilgilendirilmesi ile ilgilidir. Bilgi hasta için çok değerlidir. Hastaların bilgi mahremiyeti ile ilgili beklentisi hem tıbbi kayıtların gizliliğini hem de karar ve uygulamalarda bilgilendirerek; fiziksel, sosyal ve psikolojik mahremiyetlerinin rahatlatılmasını ve desteklenmesini içerir. ${ }^{3}$

Sağlık çalışanları, bilgi toplama, bilgi saklama, bilgi verme ve hasta bilgilerini paylaşma sırasında mahremiyet bakımından duyarlı olmadir. ${ }^{19}$ Ebe/hemşirenin gizlilik içeren bilgiyi dikkatli bir şekilde saklayarak bireyin gizlilik hakkını savunması gerekmektedir. Gizliliğin ihlali hasta bireyin ebeye ve hemşireye güven inşa etmesini olumsuz yönde etkileyerek kişilerarası ilişkilere de zarar verir. ${ }^{20}$

\section{Mahremiyet Hakkı}

Hasta haklarının başında; insan olarak sayg1 görme, mümkün olan en yüksek düzeyde sağlık hizmeti alma, bilgilendirilme, tıbbi işlemler için onay alınması, mahremiyet ve özel hayata saygı, bakım ve tedavi devamlılığının sağlanması gelmektedir. $^{21}$ Mahremiyet hakkını tanımlayan yasalar örneğin; 1973'te 27.Dünya Tıp Birliği toplantısında da; "hasta-hekim ilişkisinde gizliliğin temelinde bireyin kişisel dokunulmazliğ mahremiyeti yatmaktadır" sonucuna varılmış, Birleşmiş Milletlerde de "dünya ülkelerinde bireyin insan olmakla elde etmiş olduğu bu temel hakkı (mahremiyet hakkl) sağlamanın yolunun sirrın korunması" olduğu açıklanmıştır. ${ }^{13,22}$

$$
\text { Uluslararası Aile Planlamas1 }
$$

Federasyonu'nun (IPPF) 1995'te yayımladığı "Üreme Hakları ve Cinsel Haklar Bildirgesi” tüm bireylerin, kişisel, ev, aile ve haberleşme mahremiyetlerinin ihlal edilmemesi hakkına sahip olduklarını ve bilgilendirme ve danışmanlığın da içinde yer aldığ 1 tüm cinsel sağlık ve üreme sağlığg hizmetlerinde mahremiyet ve kişisel bilgilerin gizli kalması sağlanması 
bu bildirgenin mahremiyet hakk1 maddesinde vurgulanmıştır. ${ }^{18,23,24}$ Bireylerin özel yaşamlarının korunmasını amaçlayan mahremiyet hakkı, cinsel yaşam ve üreme hakları açısından önemlidir. Mahremiyet hakk1 bireyin bilgilerine ulaşılmazlığı, bedenine dokunulmazlığı, kendini geliştirmesi ve ifade edebilmesini kapsar. ${ }^{18}$

Hasta haklarının temel amacı hastanın desteklenmesi ve toplumsal açıdan güçlendirilmesidir. $^{21}$ Hastanın, mahremiyetine sayg1 gösterilmesi esastır. Her türlü tıbbi müdahale, hastanın mahremiyetine sayg1 gösterilerek yapılmalıdır. Mahremiyete sayg1 gösterilmesi ve isteme hakkı şunları içerir; ${ }^{25}$

a. Hastanın, sağlık durumu ile ilgili tıbbi değerlendirmelerin gizlilik içerisinde yürütülmesini,

b. Muayenenin, teşhisin, tedavinin ve hasta ile doğrudan temas1 gerektiren diğer işlemlerin makul bir gizlilik ortamında gerçekleştirilmesini,

c. Tibben sakınca olmayan hallerde yanında bir yakınının bulunmasına izin verilmesini,

d. Tedavisi ile doğrudan ilgili olmayan kimselerin, tıbbi müdahale sirasinda bulunmamasinı,

e. Hastalığın önemi gerektirmedikçe hastanın şahsi ve ailevi hayatına müdahale edilmemesini,

f. Sağlık harcamalarının kaynağının gizli tutulmasını kapsamaktadır.

g. Ölüm olayı, mahremiyetin bozulması hakkını vermez.

\section{Ebelik Uygulamalarında Mahremiyet ve Gizlilik}

Mahremiyet konusu tıbbi gizliliği çağrıştırmakla birlikte, mahremiyet ve gizlilik eş anlamlı sözcükler değildir. Ancak farklı anlamlarına rağmen, birbirlerini bütünleyici kavramlardır. ${ }^{13}$ Hekimin hastaya ait bilgileri gizli tutma ödevi, Hipokrat zamanından beri tıp etiğinin köşe taşlarından biridir. Hipokrat
Andı'nda, “Tedavi sırasında ya da hatta tedavi dışında, insanların yaşamlarına ilişkin, dışarıya yayılmaması gereken şeyler görür ya da işitirsem, bunları kendime saklayacağım ve sözünü etmeyi ayıp sayacağım." sözü yer alır. Ant ve daha yeni uyarlamaları, bilgileri gizli tutma ödevinde hiçbir ayrıcalık tanımamaktadır. Örneğin Dünya Hekimler Birliğinin Uluslararası Tıp Etiği Kuralları, "Bir hekim hastası hakkında tüm bildiklerini, hastanın ölümünden sonra bile gizli tutacaktır" ifadesine yer vermektedir. Bununla beraber başka düzenlemeler, bu mutlakçı yaklaşımı reddetmektedir. Mesleki gizlilik ilkesinin çiğnenebilme olasılığı, gizlilik düşüncesinin netleştirilmesini gerektirmiştir. ${ }^{26}$ Ebelik Andı'nda, "Bana bireylerle ilgili olarak verilen tüm bilgileri saklayacağıma, hayatı ya da sağlığı tehdit edebilecek her türlü girişimden sakınacağıma and içerim.” Sözü yer almaktadır. ${ }^{27}$

T1bbın önemli bir ahlak ilkesi olan tıbbi gizlilik, genelin esenliğine, hastanın özerkliğine ve mahremiyetine saygıyı artırmak gibi asıl amaçlara hizmet eden bir araçtır. Çünkü tıbbi gizlilik; özerklik, yararlılık, kötü davranmama ve adalet ilkeleri kapsamında anlam bulmakta ve bireyin mülkiyetine, mahremiyetine sayg1 gösterilmeyi bekleme, sırlarının korunmasını dileme hakkı gibi negatif ve pozitif hakları bütününde barındırmaktadır. Sadakat, güvenilirlik ve saygı gösterme gibi temel etik değerleri de içeren tıbbi gizlilik (sır saklama ve güven ilişkisi), temelinde de yer almakta ve bunlar doğrultusunda mutlak etik yükümlülükler yaratmaktadır. $\mathrm{Bu}$ nedenle Hipokrat Yemini, Cenova Bildirgesi, Evrensel Tip Etiği Kodları, Dünya Tıp Birliği Bildirgeleri ve Avrupa Biyoetik Sözleşmesi gibi evrensel etik kodlarda da tıbbi gizlilik gözetilmiş ve çeşitli tarihlerde günün ihtiyaçları doğrultusunda yenilenmiştir. ${ }^{13}$ The International Confederation of Midwives (ICM) dünya çapında ebelere, Ebeler için Etik Kod sunmuştur. Etik Kod ebelerin tüm 
sorularına cevap sunmayacaktır, fakat uygulamalarda yol göstermesinin yanı sira ebelik uygulamaların kalbi olan profesyonel ilişkilerin kalitesini yansıtması için bir çerçeve sağlamaktadır. ${ }^{28}$

Uluslararas1 ebelik derneklerine göre ebelik için ileri sürülen değerler; mesleki yeterlilik, bilgilendirilmiş onam, mahremiyete sayg1, çeşitliliğe sayg, kadının değerlerine ve benliğine saygıdır. ${ }^{29}$

Basit bir uygulama gibi görünen jinekolojik muayene, ebelik/hemşirelik yaklaşımında çok önemli muayene ve değerlendirme yöntemidir. Her birey alışageldiği yaşam içerisinde, ne olduğunu tam olarak bilmediği bir durum ile karşılaştığı zaman anksiyete yaşar. Jinekolojik muayene kadınlarda anksiyete yaratan bir durumdur. ${ }^{30,31}$ Kadınların çoğu, çocukluk döneminden itibaren yaşamı boyunca örtmesi, saklamas1, gizlemesi, koruması gereken genital organlarının muayenesi sirasında anksiyete ve utanma hissinden, muayene olmaktan kaçınmaya kadar değişebilen travmatize etki yaşar. ${ }^{32}$ Jinekolojik muayene kadının anksiyete yaşamasının nedenleri arasında; sağlık çalışanının olumsuz tutumu, muayene eden sağlık çalışanının karşı cinsten olması, muayene pozisyonu, kullanılan aletler, önceki olumsuz muayene deneyimleri, mahremiyete dikkat edilmemesi, ağr1 korkusu, patolojik tanı konulma korkusu, kişisel temizlik hakkında endişe, genital bölgenin çıplak olması nedeniyle utanma, cinselliğin olumsuz algılaması, muayene deneyiminin olmaması gibi nedenler yer almaktadır. ${ }^{30-33}$ Mahremiyet ile ilgili farklı alanlarda yapılmış çalışmalar tablo 1'de özetlenmiştir. Obstetrik-jinekolojik değerlendirme ve muayene esnasında kadının mahremiyetinin ihlal edilmesi kadınlarda utanma duygusu ve korkunun yoğun yaşanmasına neden olmaktadır. Bu duyguları yaşayan kadının sıra numarasına göre çağırılması, açıklama yapılmadan ve iletişime girmeden duyarsız davranarak rutin işlemleri uygulamak profesyonelliğe uygun bir yaklaşım olarak görülmemektedir. Böyle bir yaklaşım kadının sonraki muayenelerinde önemli sorunlara yol açabilmektedir. Jinekolojik kontrollerin sürekliliği için ebe/hemşirenin kadınları muayeneye hazırlayarak ilgili ve sayg1lı davranmas1, empati kurabilmesi, güler yüzlü ve açıklayıcı yaklaşması önem taşımaktadır. ${ }^{31,32,36,40}$

Tıp alanındaki tüm uygulamalarda hastanın mahremiyeti dikkate alınmalıdır. Mahremiyetin dikkate alınması gereken durumlardan birisi de doğum olayıdır. Doğum eylemi sırasında kadın, vücudunun en mahrem yerlerini ilk kez gördüğü kişilere göstermekte, uygulamalar sırasında mahremiyetini gizlemeye çalıştı̆̆ında ise çoğu zaman sağlık çalışanından olumsuz tepki görebilmektedir. ${ }^{9,40}$ Doğumda acı ve ağrı genelde beraber yaşanan deneyimlerdir. Yaşanan doğum ağrısı üzerinde pek çok fizyolojik, psikolojik ve medikal faktörlerin etkisi vardır. ${ }^{41,42}$ Amerikan Psikiyatri Enstitüsü doğumda yaşanan ağrının birçok psikolojik etkene bağl1 geliştiğini bildirmektedir. $\mathrm{Bu}$ etkenleri ise; vücuda veya ruha yönelik algisal tehdit, yardım alamamak, kontrol kayb1, ac1 veya ac1 verici bir olayın gerçekleşebileceği korkusu, bebeğinin veya kendisinin ölümü şeklinde sıralamıştır. Bunlara ek olarak annenin sosyo-kültürel özellikleri, yaşanmış deneyimler, annede ağrı ile başa çıabilmede yetersizlik, doğum öncesi eğitim almama durumu, doğumda yaşanan kaba davranışlar ve yoğun tedavinin doğum ağrısı üzerinde etkisi olduğu bildirilmektedir. Doğum ağrısının kabul edilebilir hale getirilmesi temel olarak bu etkenlerin kontrolü gerçekleşmektedir. $^{42,43}$ Niles Newton ${ }^{44}$, laboratuvar farelerinde doğum ve doğum ağrısı üzerinde çevrenin etkisini araştırmıştır. Araştırmada, doğum sancıs1 çeken farelerin mahremiyetinin sağlanmadığı ortamda korku ve stres yaşadıkları kanıtlanmıştır. Farelerde özellikle mahremiyetsiz ortamda katekolamin (stres hormonu) artışı, erken dönemde doğum ağrısını durdurmasına neden olmuştur. ${ }^{34}$ 
Tablo 1. Mahremiyet ile ilgili yapılmış çalışmalar

\begin{tabular}{|c|c|c|c|}
\hline Yazar Ad1 & Çalışmanın Adı & Çalışmanın Yeri ve Amacı & Bulgular \\
\hline $\begin{array}{l}\text { Lothian JA.( } \\
\text { 2004) }\end{array}$ & $\begin{array}{l}\text { Do Not Disturb: The } \\
\text { Importance of Privacy in } \\
\text { Labor }\end{array}$ & $\begin{array}{l}\text { Amaç: Doğum eyleminde destek } \\
\text { sağlamanın önemini tartışır. }\end{array}$ & $\begin{array}{l}\text { Çalışmada, doğada doğum yapan bir hayvanın tehdit veya rahatsız edilmesi durumunda katekolamin seviyesinin } \\
\text { doğumu durdurduğu, benzer şekilde doğum yapan kadının kendisini güvensiz ve korumasız hissettiği veya normal } \\
\text { doğum sürecinde sıkıntı yaşadığı zaman katekolamin seviyesinin yükselerek doğumu yavaşlattı̆̆ı veya durdurduğu } \\
\text { belirtilmisstir. Gereksiz uygulamalardan kaçınarak, gebenin güvenliğini sağlayarak, doğal yeteneği ile doğumu } \\
\text { gerçekleștirmesi için güven sağlayarak ve mahremiyetine saygı göstererek doğuma destek sağlamanı önemi } \\
\text { belirtilmiştir. }\end{array}$ \\
\hline $\begin{array}{l}\text { Kigenyi O, } \\
\text { Tefera GB, } \\
\text { Nabiwemba E, } \\
\text { Orach CG. } \\
\text { (2013) }\end{array}$ & $\begin{array}{l}\text { Quality of Intrapartum } \\
\text { Care at Mulago National } \\
\text { Referral Hospital, } \\
\text { Uganda: Clients' } \\
\text { Perspective }\end{array}$ & $\begin{array}{l}\text { Yer: Mulago Hastanesi } \\
\text { Amaç: Kadınların bakış açısılla doğum } \\
\text { salonunda intrapartum bakım } \\
\text { hizmetlerinin kalitesini değerlendirmek } \\
\text { amacıyla yapılmıştır. }\end{array}$ & $\begin{array}{l}\text { Bu çalışma, hastaların bakış açısıyla intrapartum bakım hizmetlerinin kalitesinin düşük olduğunu ortaya } \\
\text { koymaktadır. Kişinin durumu, bakımı hakkında karar ve bilgi verirken hasta odaklı olunması, mahremiyet ve } \\
\text { gizliliğin sağlanması gerektiği belirtilmektedir. Ayrıca doğumhanede sağlık hizmeti verenlerin sayısının ve } \\
\text { etkinliğinin artırılması gerektiği belirtilmektedir. }\end{array}$ \\
\hline $\begin{array}{l}\text { Sarpkaya D, } \\
\text { Vural G. } \\
\text { (2014) }\end{array}$ & $\begin{array}{l}\text { Hemşirelikte Dört Bilme } \\
\text { Yolunun Jinekolojik } \\
\text { Muayenede Kullanımı }\end{array}$ & $\begin{array}{l}\text { Amaç: Hemşirelikte dört bilme yolunun } \\
\text { jinekolojik muayenede kullanımını } \\
\text { örneklendirmek amacı ile hazırlanmıştır. }\end{array}$ & $\begin{array}{l}\text { Hemşirelikte dört bilme yolunu, empirik bilmenin bilimsel yeterliliğini, etik bilmenin ahlaki ve etik davranışlarını, } \\
\text { kişisel bilmenin bilgi ve becerisini etkin kullanabilmesini ve estetik bilmenin her hastaya karşı değişebilen sanatsal } \\
\text { davranışlarını tanımladığını ifade etmektedir. Dört bilme yolu kullanılarak hemşirelik bilgisinin geliştirilebileceğini } \\
\text { bunun sonucunda, profesyonel hemşirenin, kadınların jinekolojik muayenelerini düzenli olarak yaptırmalarına } \\
\text { olanak sağlayarak topluma iyi bir hizmet vermiş olacağını belirtilmektedir. }\end{array}$ \\
\hline $\begin{array}{l}\text { Erbil N, Şenkul } \\
\text { A, Sağlam Y, } \\
\text { Ergül N. (2008) }\end{array}$ & $\begin{array}{l}\text { Jinekolojik muayene } \\
\text { öncesinde Türk } \\
\text { kadınların anksiyete } \\
\text { seviyeleri ve muayeneye } \\
\text { ilişin tutumlarının } \\
\text { belirlenmesi }\end{array}$ & $\begin{array}{l}\text { Yer: Türkiye'nin Ordu ilinde bulunan } \\
\text { Kadın-Doğum ve Çocuk Hastalıkları } \\
\text { Hastanesi Jinekoloji Polikliniği } \\
\text { Amaç: Jinekolojik muayene öncesinde } \\
\text { Türk kadınların anksiyete seviyeleri ve } \\
\text { muayeneye ilişkin tutumlarının } \\
\text { belirlenmesidir. }\end{array}$ & $\begin{array}{l}\text { Kadınları \%67,1'i mahrem organını göstermenin ve \%39,6's doktorun yaklaşımının rahatsılılık verdiğini, \%62,5'i } \\
\text { utanma, \%38,8'i ikıntı, \% } \% 37,9 \text { 'u korku, \%21,7'si ağrı yaşadığını, sağlık çalışanlarından güler yüz, ilgi ve anlayış } \\
\text { bekledikleri belirtilmiştir. }\end{array}$ \\
\hline $\begin{array}{l}\text { Güngör İ. } \\
\text { (2009) }\end{array}$ & $\begin{array}{l}\text { Doğumda Anne } \\
\text { Memnuniyetini } \\
\text { Değerlendirme } \\
\text { Ölçeğinin Geliştirilmesi } \\
\text { (Doktora Tezi) }\end{array}$ & $\begin{array}{l}\text { Yer: İstanbul Üniversitesi Tıp Fakültesi } \\
\text { Kadın Hastalıkları ve Doğum Anabilim } \\
\text { Dalı } \\
\text { Amaç: Annelerin doğumda ve } \\
\text { hastaneden taburcu olmadan önce erken } \\
\text { postpartum dönemdeki deneyimlerini } \\
\text { değerlendirmek üzere kullanılabilecek } \\
\text { 'Doğumda Anne Memnuniyetini } \\
\text { Değerlendirme Ölçeği'nin } \\
\text { geliştirilmesidir. }\end{array}$ & $\begin{array}{l}\text { Doğum şekline özgü olarak normal ve sezaryen doğum versiyonlarını içeren iki ayrı ölçek geliş̧tirilmiştir. Ölçekler } \\
10 \text { alt boyutta toplanmıştır. Bunlar; Sağlık Ekibini Algılayışı, Doğum Eyleminde Hemşirelik Bakımı (bu faktörün } \\
\text { yerine sezaryen doğumda 'Sezaryene Hazırlık' yer almaktadır), Rahatlatma, Kararlara Katılım ve Bilgilendirme, } \\
\text { Bebekle Tanışma, Postpartum Bakım, Hastane Odası, Hastane Olanakları, Mahremiyete Saygı ve Beklentilerin } \\
\text { Karşılanmasıdır. }\end{array}$ \\
\hline $\begin{array}{l}\text { Özmen N. } \\
(2012)\end{array}$ & $\begin{array}{l}\text { Jinekolojik muayene } \\
\text { sırasında kadınların } \\
\text { hemşirelik } \\
\text { yaklaşımlarına yönelik } \\
\text { aldıkları hizmetler ve } \\
\text { beklentileri }\end{array}$ & $\begin{array}{l}\text { Yer: Zekai Tahir Burak Kadın Sağlı̆̆ } \\
\text { Eğitim ve Araşırma Hastanesi } \\
\text { Jinekoloji Polikliniği } \\
\text { Amaç: Jinekolojik muayene sırasında } \\
\text { kadınların hemşirelik yaklaşımlarına } \\
\text { yönelik aldıkları hizmetler ve } \\
\text { beklentilerinin belirlenmesidir. }\end{array}$ & 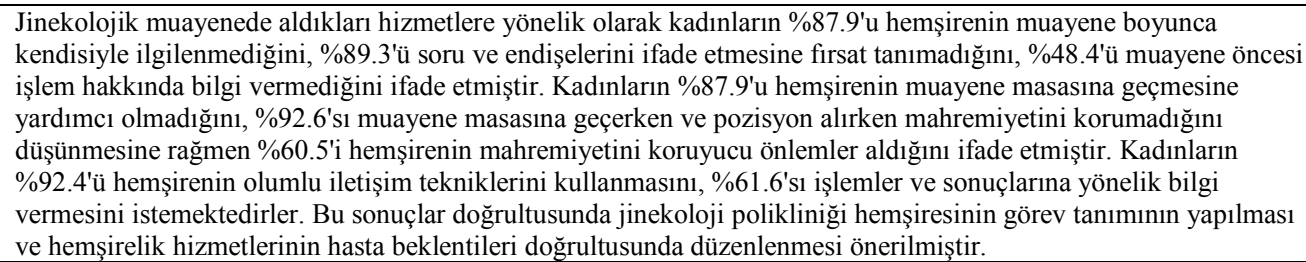 \\
\hline $\begin{array}{l}\text { Lay MM. } \\
\text { (2003) }\end{array}$ & $\begin{array}{l}\text { Midwifery on Trial: } \\
\text { Balancing Privacy } \\
\text { Rights and Health } \\
\text { Concerns after Roe v. } \\
\text { Wade }\end{array}$ & $\begin{array}{l}\text { Amaç: Bu makalede, } 1970 \text { 'lerde } \\
\text { Kaliforniya'da ve 1990'larda New } \\
\text { York'ta geleneksel ebeleri içeren beş } \\
\text { dava incelemektedir. }\end{array}$ & $\begin{array}{l}\text { Gebe kadınlar için tıbbi bir bakım veren Roe Wade, belirsizlik veya ikinci planda bırakıldığ için; mahkemeler yeni } \\
\text { tanımlanmış mahremiyet hakları çerçevesinde kimin tıbbi danışman olabileceğine karar vermek amacıyla Roe } \\
\text { davası sonrası yasal tıp çerçevesi ile uğraşmıștı. Mahkemeler aynı zamanda bireysel mahremiyet haklarını } \\
\text { dengelemek için sağlık uygulamalarında ve yaşamda sınırları belirlemek ve bakım verenlerle hasta arasında tıbbi } \\
\text { otoriteyi belirlemek için uğraşmışlardır. }\end{array}$ \\
\hline
\end{tabular}


Michal Odent ${ }^{45}$, doğumun istemsiz bir süreç olduğunu ve istemsiz sürece müdahale edilememesi gerektiğini belirtmiştir. Normal, doğal ve fizyolojik doğum ağrısının hassas sürecinin ilerletilmeye ihtiyac1 yoktur. Doğum ağrısı ve doğumun hormonal uyumunu bilmek, fizyolojik sürece müdahale edilmemesi gerektiğinin önemini anlamamızı sağlamaktadır. Doğumun erken evrelerinde, katekolamin doğum ağrılarını durdurma potansiyeline sahiptir. Doğuma gelen gebenin; acidan, hastaneden, bilinmeyen durumlardan korkması, doğumun ilerlemesinde başarısızlı̆̆a neden olabilmektedir. $^{34}$ Doğumda kadınlar, bilmediği ortamda bulunma, mahremiyetini koruyamama ve doğum süreci ile baş etmeye çalışmaktadırlar. Kadınlar yaşadıklarını ve olup bitenleri yeterince bilmedikleri ve anlayamadikları için doğumda korku, endişe ve anksiyete yaşamaktadırlar. Kadınlar doğum eylemi ile baş etmek ve sağlıklı bir doğum süreci geçirmek için destek almaya ve önemsendiğini hissetmeye gereksinim duymaktadırlar. Doğum eylemi süresince verilen profesyonel destek, kadının kontrol duygusunu geliştirmesine ve doğum ağrısı ile baş etmesine yardım ederek olumsuz deneyim yaşamasını önleyebilmektedir. ${ }^{46,47}$ Gebelik ve doğum değer-yüklü deneyimlerdir. Ebeler bütüncül yaklaşımla bu deneyimler sirasinda annelerin ve bebeklerin fiziksel, eğitimsel, psiko-sosyal ve ihtiyaçlarını sağlamaktadırlar. Gebelik, doğum süreci, doğum sonrası ve yenidoğan dönemi boyunca kadınlara bakım veren olarak birçok rolleri bulunmaktadır. Doğum, resüsitasyon, kontrasepsiyon, yardımcı üreme teknikleri, kürtaj, şiddete maruz kalan kadına yardım gibi konularda kendi kişisel ve mesleki değerlerinden köken alan kritik kararlar almak zorundadırlar. $^{48}$ Ebeler, kadınların en hassas dönemlerinde yanlarında bulundukları için uygulamalarda mahremiyete önem vermeleri gerekmektedir.
Muayene, tedavi ve tanisal işlemlerde hastanın bedenini, özel hayatını açmasını, sırlarını açıklamasını gerektiren işlemler belirli bir mahremiyet ortamında gerçekleştirilmelidir. Sağlık çalışanı bu işlemler esnasında tercihen bir yardımcı bulundurmalidir. Tibben sakınca olmayan durumlarda hastanın bir yakınının bulunmasına izin verilebilir. Eğitim verilen sağlık kuruluşlarında, uygulamaya çıkan öğrencilerin tıbbi işlemler sırasında bulunması gerekli ise bunun için hastanın onayının alınması önemlidir. ${ }^{49}$

Mahremiyet, sağlık bakımı alanların psikolojik fonksiyonlarını desteklediğinden dolayı önemlidir. Mahremiyet duygusu, hastalara açıklanan bilginin başkalarına yayılmayacağı güvenini verirken dürüst ve doğru iletişim için cesaret vermektedir. Kendisi hakkında çoğu bilginin birinden diğerine ulaştırıldığ mahremiyetsiz bir çevrede, huzursuz olacağından istekler ciddi şekilde gizlenebilir. Hastalar, cinsel problemler, üriner enfeksiyon için ilaç kullanımı, rektal veya intravajinal ilaç alımı gibi konularda tavsiyeler alırken mahremiyete dikkat edilmelidir. $^{50}$

Bireyin mahremiyet hakkının tanınması ve saygı gösterilmesi, kişisel kontrolünün sürdürülmesi ve desteklenmesi ile doğrudan ilişkili olan özdeğerin korunması, kararlara katılım, ilişskilerin ve konforun iyiliği, müşteri memnuniyeti gibi sonuçlar temel kalite göstergeleri olarak kabul edilmeye başlanmıştır. Kaliteli hizmeti hedefleyen sağlık kurumları için, genel olarak hasta haklarının, özellikle mahremiyetin ve bilgilerin gizliliğinin korunmasına yönelik yasal ve kurumsal düzenlemelerin oluşturulması ve işlerliğinin sağlanması vazgeçilmez öğelerdir. ${ }^{51}$

\section{Sonuç ve Öneriler}

Sağlık hizmetlerinin sunumunda insan ve üreme hakları içinde temel alınan bir değer olan mahremiyete sayg1 gösterilmesi başta jinekolojik muayene, doğum, tedavi ve tanısal işlemler olmak üzere hizmet verilen 
tüm alanlarda özenle dikkat edilmelidir. Jinekolojik muayene sonucu erken dönemde jinekolojik kanserler tanılamalarının yapılabilmesi için özendirici tedbirler almak öncelikli hedef olmalıdır. Ayrıca insan hayatında en önemli olaylardan biri olan doğumun hatıralarda güzel bir anı olarak kalması bir kadının en temel hakkıdır. Böyle deneyimlerin kadın açısından olumlu olması ebenin ilgisi, ortamın temizliği ve konforu, kibar ve saygilı hizmet, mahremiyete saygı gösterilmesine bağlıdır. $\mathrm{Bu}$ amaçla ebe öğrencilerin ders konuları içinde, mahremiyet konusuna yeterince yer verilmelidir. Çalışan ebelerin mahremiyet konusunda etkinliğini artırmak için eğitim programları düzenlenmeli ve farkındalık oluşturulmalıdır. Ayrica bu konu ile ilgili kalitatif ve kantitatif çalışmaların yapılması önerilmektedir.

\section{Kaynaklar}

1. Atabek EA, Karada ğ A. [Nursing fundamentals: science and principles of nursing] Hemşirelik esasları: hemşirelik bilimi ve esasları. İstanbul: Akademi Basım ve Yayıncılik; 2013. s. 1136.

2. Birol L. [Nursing Process] Hemşirelik Süreci. İzmir: Etki Matbaac1l1k; 2011. s. 14.

3. Akyüz E, Erdemir F. Surgical patients' and nurses' opinions and expectations about privacy in care. Nursing Ethics 2013;20: 660-671.

4. Woogara J. Human rights and patients' privacy in UK hospitals. Nursing Ethics 2001;8: 234-246.

5. Altman I. Privacy regulation: culturally universal or culturally specific? Journal of Social Issues 1977;33: 66-84.

6. Leino-Kilpi H, Välimäki M, Dassen T, Gasull M, Lemonidou C, Scott A, Arndt M. Privacy: a review of the literature. International Journal of Nursing Studies 2001;38(6): 663671.
7. Türk Dil Kurumu. Erişim Adresi: http://www.tdk.gov.tr/ Erişim Tarihi: 08.12.2014.

8. İzgi MC. [The concept of privacy in the context of personal health data] Mahremiyet kavramı bağlamında kişisel sağl1k verileri. Türkiye Biyoetik Dergisi 2014;1(1):25-37.

9. Taşçı KD. [Evaluation of patients to received care after birth from the aspect of patient rights] Doğum yapan hastaların algıladıkları bakımı hasta hakları açısından değerlendirmeleri. Atatürk Üniversitesi Hemşirelik Yüksekokulu Dergisi 2007; 10(3):26-33.

10. Yüksel M. [The right of privacy and its socio,historical development] Mahremiyet hakkı ve sosyo-tarihsel gelişimi. Ankara Üniversitesi SBF Dergisi 2003; 58: 181-213.

11. Diler R. [Education of privacy and the 1t's 1mportance] Mahremiyet eğitimi ve önemi. Gaziosmanpaşa Üniversitesi Ilahiyat Fakültesi Dergisi 2014; 2: 70-98.

12. İnan M. [Privacy: discussion of specific areas belonging to person] Mahremiyet: Kişiye ait özel alan tartışmaları. Sakarya Üniversitesi Ilahiyat Fakültesi Dergisi 2008; 18: 203-209.

13. Ersoy N. [Privacy in medicine: scope and exceptions] Tip'ta mahremiyet: Kapsamı ve istisnaları. Erişim Adresi: tip.kocaeli.edu.tr/docs/.../Tipta_ma hremiyet-kapsami_ve_istisnalari. Erişim Tarihi:25.12.2014.

14. Coyle J. Spirituality and health: towards a framework for exploring the relationship between spirituality and health. Journal of Advanced Nursing 2002; 37: 589-597.

15. Walter T. Spirituality in palliative care: opportunity or burden? Palliative Medicine 2002; 16: 133139. 
16. Wright M. The essence of spiritual care: a phenomenological enquiry. Palliative Medicine 2002; 16: 125132.

17. Ergül Ş, Bayık A. [Nursing and spiritual care] Hemşirelik ve manevi bakım. C. $\ddot{U}$. Hemşirelik Yüksekokulu Dergisi 2004; 8(1): 37-45.

18. Sert G. [Reproductive rights with case in Turkey] Vakalarla Türkiye'de üreme hakları. İstanbul: Turap Tanıtım Yayınları; 2013. s. 14-17.

19. Meier E. Medical privacy and its value for patients. Seminars in Oncology Nursing 2002; 18(2): 105-108.

20. Yalçın N, Aștı T. [Nurse-patient interaction] Hemşire-hasta etkileşimi. Florence Nightingale Hemşirelik Dergisi 2011; 19: 5459.

21. Erbil N. [Developing scale of patient' rights using attitude] Hasta haklarını kullanma tutumu ölçeğinin geliştirilmesi. Uluslararast Insan Bilimleri Dergisi 2009; 6: 825-838.

22. Sağlık Mevzuatı: Tıbbi Deontoloji Nizamnamesi. Hacettepe Yayın Birliği, Ankara, 611-617, 1987.

23. IPPF Üreme Hakları ve Cinsel Haklar Bildirgesi, Vizyon 2000, Uluslararas1 Federasyonu - 1996, Türkiye Aile Planlaması Derneği Yayınları, No. 54, 1997.

24. Yanıkkerem E, Saruhan A, Şirin A. [Mother rights aspects of safe motherhood] Güvenli annelik açısından anne hakları. TSK Koruyucu Hekimlik Bülteni 2008; 7 (2): 179-186

25. Hasta Hakları Yönetmeliği. Resmi Gazete Tarihi: 01.08. 1998, Resmi Gazete No: 23420. Erişim Tarihi: 21.10.2014.

26. Civaner M. [World medical association medical ethics manual] Dünya hekimler birliği tıp etiği el kitabı. Ankara: Türk Tabipler Birliği Yayınları; 2005. s. 34-60.

27. Daşdibi Beydilli E. [Yesterday and today of midwifery] Ebeliğin dünü ve bugünü. 1 ed. Ankara: Alter Yayıncilik 2007. s. 119.

28. Thompson A. Ethics in midwifery. Bennett VR, Brown, LK (Eds.). 13 ed. India: Churchill Livingstone; 2000. s. 67-79.

29. Ergin A, Özcan M, Acar Z, Ersoy $N$, Karahan N. Determination of national midwifery ethical values and ethical codes In Turkey. Nursing Ethics 2013;20(7):808818.

30. Mete S. [The effects of nursing approach to the alleriatation anxiety of the women coming the jynecologic examination] Jinekolojik muayeneye gelen kadınlarda oluşan anksiyeteye hemşirelik yaklaşımının etkisi. $C$. Ü. Hemşirelik Yüksekokulu Dergisi 1998; 2(2): 1-8.

31. Altay B, Kefeli B. [The effect of some variables to the alleriatation anxiety of women who came for jynecologic examination] Jinekolojik muayeneye gelen kadınların anksiyete düzeyi ve etkileyen bazı faktörler. Dokuz Eylül Üniversitesi Hemşirelik Yüksekokulu Elektronik Dergisi 2012; 5(4): 134-141.

32. Erbil N, Şenkul A, Sağlam Y, Ergül N. [Determination of attitudes with gynecologic examination and anxiety of Turkish women before gynecologic examination] Jinekolojik muayene öncesinde Türk kadınların anksiyete seviyeleri ve muayeneye ilişkin tutumlarının belirlenmesi. Uluslararast Insan Bilimleri Dergisi 2008; 5(1): 1-13.

33. Hilden M, Sidenius K, LanghoffRoos J, Wijma B, Schei B. Women's experiences of the gynecologic examination: factors associated with discomfort. Acta 
Obstetricia Et Gynecologica Scandinavica 2003; 82: 1030-1036.

34. Lothian JA. Do not disturb: the importance of privacy in labor. The Journal of Perinatal Education 2004; 13: 4-6.

35. Kigenyi O, Tefera GB, Nabiwemba E, Orach CG. Quality of intrapartum care at Mulago national referral hospital, Uganda: clients' perspective. BMC Pregnancy and Childbirth 2013; 13: 162-170.

36. Sarpkaya D, Vural G.[ The use of the way of knowing four in gynaecological examination in nursing] Hemşirelikte dört bilme yolunun jinekolojik muayenede kullanımı. Dokuz Eylül Üniversitesi Hemşirelik Yüksekokulu Elektronik Dergisi 2014; 7(2):124-127.

37. Güngör İ. Doğumda anne memnuniyetini değerlendirme ölçeğinin geliştirilmesi. [Development of a scale for measuring maternal satisfaction in birth] [Doktora Tezi]. İstanbul Üniversitesi Sağlık Bilimleri Enstitüsü [Institute of Health Sciences, İstanbul University], İstanbul, Türkiye, 2009.

38. Özmen N. Jinekolojik muayene sırasında kadınların hemşirelik yaklaşımlarına yönelik aldıkları hizmetler ve beklentileri. [The nursing services concerning nursing approaches and expectations of women during gynecological examination] [Yüksek Lisans Tezi]. Hacettepe Üniversitesi Sağlık Bilimleri Enstitüsü [Institute of Health Sciences, Hacettepe University], Ankara, Türkiye, 2012.

39. Lay MM. Midwifery on Trial: Balancing Privacy Rights and Health Concerns after Roe v. Wade. Quarterly Journal of Speech 2003, 89(1):60-77.

40. Taşkın L. [Women's health and diseases nursing] Kadın sağlığ 1 ve hastalıkları hemşireliği. 11. Baskı.
Ankara: Sistem Ofset Matbaacılik; 2012. s. 413-427.

41. Yıldırım G. Doğum eyleminde uygulanan 1kınma tekniğinin anne ve fetüs üzerindeki etkileri [The effects of pushing techniques on mother and fetus in birth] [Doktora Tezi]. İstanbul Üniversitesi Sağlık Bilimleri Enstitüsü [Institute of Health Sciences, Istanbul University], İstanbul, Türkiye, 2005.

42. Köksal Ö, Duran ET. [Cultural approach for labor pain] Doğum ağrısına kültürel yaklaşım. Dokuz Eylül Üniversitesi Hemşirelik Yüksekokulu Elektronik Dergisi 2013, 6(3):144-148.

43. Yıldız N. İlaçsız ağrı kontrol yöntemlerinden tens'in doğum ağrısını algılamaya etkisi [The effectiveness of tens for pain relief in labor] [Yüksek Lisans Tezi]. Marmara Üniversitesi Sağlık Bilimleri Enstitüsü [Institute of Health Sciences, Marmara University], İstanbul, Türkiye, 2003.

44. Newton N, Foshee D, Newton M. Experimental inhibition of labor through environmental disturbance. Obstetrics \& Gynecology 1966;27(3):371-377.

45. Odent M. The fetus ejection reflex. Birth 1987;14(2):104-105.

46. Adams ED, Bianchi AL. A practical approach to labor support. Journal of Obstetric, Gynecologic, \& Neonatal Nursing 2008; 37: 106115.

47. Chen $\mathrm{CH}$, Wang SY, Chang MY. Women's perceptions of helpful and unhelpful nursing behaviors during labor: A study in Taiwan. Birth 2001; 28: 180-185.

48. Özcan M, Akpınar A, Ergin AB. Personal and professional values grading among midwifery students. Nursing ethics 2012;19(3):399-407. 
49. Arısoy Y. [Legal responsibilities of healthcare workers] Sağlık çalışanlarının hukuki sorumlulukları. Dokuz Eylül Üniversitesi Hemşirelik Yüksekokulu Elektronik Dergisi 2009; 2(4): 183-187.

50. Mobach MP. Counter design influences the privacy of patients in health care. Social Science \& Medicine 2009; 68: 1000-1005.

51. Üzeltürk S. [1982 Constitution and Human Rights, the right to privacy under the European Convention] 1982 Anayasası ve İnsan Hakları Avrupa Sözleşmesine göre özel hayatın gizliliği hakkı. İstanbul: Beta Yayınc1l1k; 2004. s. 99-109. 